Wenke Mork Rogne

Høgskulen i Volda

Siv Måseidvåg Gamlem

Høgskulen i Volda

Randi Lyngbø Ottesen

Høgskulen i Volda

DOI: http://dx.doi.org/10.5617/adno.8327

\title{
Lese- og skriveferdigheter ved oppstart i 1. klasse med vekt på bokstavkunnskap
}

\section{Sammendrag}

Studien analyserer de tidlige lese- og skriveferdighetene til et utvalg norske elever ved skolestart på 1. trinn (6 år gamle). Målet er å fremheve noen sentrale variabler som kjennetegner ferdigheter for elever i bokstavkunnskap, og hvilke lese- og skriveferdigheter de strever med i starten av 1. klasse. Resultatene viser store forskjeller mellom de ca. $20 \%$ av elevene med lavest skår i bokstavkunnskap $(n=109)$ og resten av utvalget ( $n=468)$, når det gjelder ulike lese- og skrivemål, men særlig er forskjellen stor når det gjelder bokstavgjenkalling og fonologisk analyse. Resultatene fremhever variablene som karakteriserer ferdighetene til elever med lav mestring i lesing og skriving, og gir kunnskap for lærere som kan styrke opplæringen for denne elevgruppen.

Nøkkelord: lese- og skriveferdigheter, bokstavkunnskap, begynneropplæring, tidlig innsats

\section{Literacy skills in grade 1 based on letter knowledge}

\begin{abstract}
This study analyzes the early literacy skills of a sample of Norwegian pupils in grade 1 (6 years old). The aim is to highlight central variables that characterize skills of pupils and what literacy skills they struggle with related to letter knowledge in the beginning of grade 1 . The results show great differences between the approximately $20 \%$ of the pupils with lowest score in letter knowledge $(n=109)$ and the rest of the sample $(n=$ 468) in various literacy measures, but specifically large differences are found in the variables of letter recall and phonological analysis. The results highlight some important variables that characterize the literacy skills of pupils with low mastery in reading and writing. This brings knowledge to teachers that can strengthen the teaching for this group of pupils.
\end{abstract}

Keywords: early literacy skills, letter knowledge, beginner training, early intervention 


\section{Introduksjon}

Denne studien undersøker lese- og skriveferdighetene til et utvalg norske elever ved skolestart i 1. klasse. Studien belyser noen av delkomponentene elever strever med i lese- og skriveopplæringen. Studien, som er en del av forskningsrådsprosjektet DigiHand, tar i bruk kvantitative målinger av bokstavkunnskap, fremlydsanalyse, bokstavgjenkalling, fonologisk syntese, lesing av ord, staving av ord og vokabular.

Systematisert språkkartlegging fra barnehagealder har vært omdiskutert og til dels polarisert (se Klem \& Hagtvet, 2018, for gjennomgang). Argumentet for tidlig kartlegging er språkpedagogisk og spesialpedagogisk begrunnet, og kartlegging blir fremhevet som en etisk forpliktelse til å sikre at alle barn får best mulige vilkår for utvikling og læring. Det blir argumentert for at tidlig kartlegging er viktig for barn som har behov for intensivert språkstøtte for å få tilpasset pedagogiske tiltak og oppfølging (Klem \& Hagtvet, 2018). Barn som strever med språket ved skolestart kan komme inn i negative og selvforsterkende utviklingssirkler. Dette kan være hemmende for barns læring og fungering i skolen og i samfunnet generelt (Hulme \& Snowling, 2009). Tidlig og systematisert språkkartlegging kan derfor benyttes i skoler og barnehager.

Formålet med studien er å undersøke hva som kjennetegner lese- og skriveferdighetene til elever i et utvalg på 33 skoler $(n=577$ elever). Et delutvalg på $18,9 \%$ av de 577 elevene i studien er basert på tidligere forskning av Walgermo (2018) og det faktum at 20 \% tilsvarer andelen elever som får forsterket undervisning eller spesialundervisning i 1. klasse (UDIR, 2020). Siden 20-prosentilen til elevenes skårverdier på variabelen bokstavkunnskap faller mellom 11 og 12 poeng på skalaen i studien vår, ble det bestemt at alle elevene som skåret lavere enn 12 poeng skulle utgjøre dette delutvalget. Delutvalget inneholder 109 elever og blir i artikkelen kalt gruppe 1 . Resten av utvalget kalles gruppe 2 og inneholder 468 elever.

Det kan være stor variasjon i elevers bokstavkunnskap i starten av 1. klasse, og det er lite forskning på hvilke delkomponenter i språkinnlæringen elever strever med. Problemstillingen for studien er følgende:

Hva kjennetegner lese- og skriveferdighetene til et utvalg elever ved oppstart på 1. trinn?

\section{Teoretisk rammeverk}

Elever i 5-6-årsalderen går gjennom en lese- og skriveutvikling i ulike stadier (Spear-Swerling \& Sternberg, 1994), og det er stor individuell variasjon i de tidlige lese- og skriveferdighetene når de begynner på skolen (Walgermo, 2018). Ifølge forskere er bokstavkunnskap og fonologisk bevissthet de viktigste faktorene som bidrar til senere lese- og skriveferdigheter (Lonigan et al., 2000; 
Walgermo, 2018). Før skolestart, og før elevene har lært å lese og skrive, vil tidlige språkferdigheter (emergent literacy) være en mer korrekt benevnelse, men i denne studien er vi opptatt av delferdigheter som er knyttet til utvikling av lesing og skriving, og som inngår i senere lese- og skriveferdigheter.

Ordavkodingen er forbundet med leseferdighet og er betegnet som den «tekniske» delen av lesingen, mens lytteforståelsen gjerne har blitt oppfattet som lesingens språklige faktor (Gough \& Tunmer, 1986; Hoover \& Gough, 1990). Dette har også blitt kalt «The simple view of reading» (Gough \& Tunmer, 1986; Hoover \& Gough, 1990), en forenklet modell som ikke kan forklare hele variansen av den mer komplekse leseferdigheten (Chen \& Vellutino, 1997; Georgiou et al., 2009). Ordavkodingsprosessen synes å være sterkt relatert til bearbeidingen av språkets fonologiske elementer. Barns evne til å gjenkjenne, bearbeide og gjenkalle språkets fonologiske struktur, lydstrukturen, synes å danne et svært viktig grunnlag for et barns lese- og skriveutvikling (Cain, 2010; Gough \& Tunmer, 1986; Hoover \& Gough, 1990).

Ofte har det vært elevens evne til å avkode ord, mer enn forståelsen av ord og teksten de inngår i, som har hindret en rekke barn i å utvikle gode leseferdigheter (Spear-Swerling \& Sternberg, 1994; Torgesen, 1991). Videre viser ulike studier at barn som har svake leseferdigheter første skoleår, vil ha mer enn 90 \% risiko for å få svake leseferdigheter senere (Chard \& Kameenui, 2000; Walgermo, 2018). Barnets fonologiske utvikling og evne til å bearbeide og manipulere språkets lydstruktur vil kunne skape store individuelle forskjeller i den språkutviklingsprosessen som finner sted. Selv om vanskene i noen tilfeller kan forklares biologisk, vil miljømessige faktorer som lærerinstruksjon også kunne spille inn (Alexander et al., 1991). Ved å fremheve viktigheten av god instruksjon og sosiale og miljømessige faktorer, vil man samtidig fremheve betydningen lærere og andre har for å støtte elever med risiko for å utvikle lesevansker (Alexander et al., 1991; Spear-Swerling \& Sternberg, 1994).

I tillegg til ordavkoding vil det også være andre faktorer som spiller inn på språkutviklingen, og som skaper forskjeller mellom elevene utover det ordavkodingsferdighetene og lytteforståelsen kan forklare. Cain (2010) hevder at en bevissthet om skrift, kunnskap om bokstavnavn, lyder til bokstavene i alfabetet, og fonologiske prosesseringsevner alle forutsier hvor lett barnet vil lære å lese. Fonologiske prosesseringsevner inkluderer fonologisk bevissthet, verbal korttidshukommelse, bokstavkunnskap og bokstavgjenkalling. Fonologisk omkoding er en ferdighet som bidrar til elevenes leseforståelse. Selv om de enkelte lydelementene som et ord utgjør, i seg selv ikke bærer betydning, er det realiseringen av et ords fonemstruktur som bærer betydning (Cain, 2010). Det innebærer at når lyd for lyd legges til en «lydpakke» som bygges opp med utgangspunkt i et skrevet ord, vil leseren være på stadig jakt etter mening i den lydstrukturen som trer frem. Selv ved lesing av enkeltord kan det være at barnet foregriper ordet ut fra en delvis fonologisk omkoding og søker en mening i sitt leksikon, eller språklager, ut fra omkodingen som har funnet sted (Cain, 2010). Språkutfordringer i tidlig alder kan 
i tillegg til omkoding også skyldes andre faktorer som for eksempel problemer med fonologisk prosessering og muntlig språk (Nation, 2019).

\section{Lese- og skriveferdigheter hos barn i tidlig alder}

Variasjonen i lese- og skriveferdigheter hos barn i førskolealder kan skyldes ulike faktorer, som for eksempel fonologisk syntese og bokstavkunnskap. En metaanalyse av 21 studier og 95 artikler viser at barn med risiko for å få dysleksi viser språkproblemer allerede tidlig i barnehagealder (Snowling \& Melby-Lervåg, 2016). For elever med risiko for å få dysleksi ser også leseforståelsen ut til å være lav (Shaywitz et al., 1999), noe som kan være en direkte konsekvens av svak avkoding (Gough \& Tunmer, 1986; Snowling et al., 2019). I tillegg kan lave ferdigheter i fonologisk syntese og analyse være en risikofaktor for å utvikle dysleksi hos barn (Snowling et al., 2019).

Andre studier viser at det er forskjell mellom elever som har risiko for å utvikle dysleksi og elever som kan slite med utviklingsmessige språkvansker, eller «Developmental Language Disorder» (DLD) (Snowling et al., 2019). En studie av Snowling et al. (2019) viste at elever med risiko for dysleksi kan ha problemer med fonologi og spesifikke språkferdigheter før skolestart, mens elever med DLD, med eller uten dysleksi, i tillegg kan ha problemer med utførelse av motoriske oppgaver. Det viser seg også at barn med DLD kan ha mer utvidede språkproblemer, for eksempel med vokabular, grammatikkforståelse og overflatisk prosessering, samt svak bokstavkunnskap (Catts et al., 2002; McArthur et al., 2000).

\section{Vokabular og leseforståelse}

Vokabularet (ordforrådet) har betydning for elevers språkutvikling, og elever som begynner på skole har et utvidet vokabular og mestrer de fleste syntaktiske mønstre (Lyster, 2009). Barnet forstår gjerne flere ord, uttrykk og setningsstrukturer enn det selv bruker, og vil etter hvert også ta denne språklige kunnskapen i bruk. Metaanalyser av longitudinelle studier viser sammenhenger mellom vokabular og leseforståelse i førskolealder, og mellom ordforråd og senere leseferdigheter, både avkoding og lytteforståelse (Hagtvet et al., 2011). Det er imidlertid store forskjeller mellom elevene når det gjelder barns vokabular ved skolestart, og denne forskjellen vil kunne utvikle seg dramatisk hvis ikke vokabularet får en sentral plass i undervisning og i læringsaktiviteter i leseopplæringen (Biemiller, 2005). Studier viser at det er sammenheng mellom vokabular og ordavkodingen (Hagtvet et al. 2011; Ouellette, 2006). I en longitudinell studie av Hulme et al. (2015) fant de at språkferdigheter (lingvistisk forståelse) når barnet var 3,5 år, bidro direkte til leseforståelsen hos elevene når de var 8,5 år. Andre studier viser også at elevens tidlige lese- og skriveferdigheter påvirker barnets selvoppfattelse, men ikke nødvendigvis barnets interesse for lesing og skriving (Walgermo et al., 2018; Walgermo, 2018). 


\section{Bokstavkunnskapens betydning}

Sikker bokstavkunnskap, eller kunnskap om bokstavene, er en viktig forutsetning for en god lese- og skriveutvikling. I mange år har det vært gjeldende praksis å gå sakte frem for å sikre å få alle elevene med i prosessen, men praksisen har vært basert mer på tradisjon enn på forskning. Få studier har likevel undersøkt norske barns bokstavkunnskaper ved skolestart, men to nyere studier gir imidlertid noe innsikt. Sigmundsson et al. (2017) fant at barn i gjennomsnitt kunne navngi færre enn halvparten av både store og små bokstaver i det norske alfabetet ved skolestart. McTigue et al. (2020) fant at de fleste elevene kunne kjenne igjen store bokstaver, men at svært få elever var lesere ved skolestart. I begge studiene var det stor variasjon i elevene sine språkferdigheter. En metastudie av Hagtvet et al. (2011) viste også at fonologisk bevissthet og bokstavkunnskap fremstår som særlig viktige faktorer i begynneropplæringen, og er med på å styrke barns vokabular.

\section{Metode}

Studien har en kvantitativ tilnærming, basert på mål for lese- og skriveferdigheter i starten av første klasse. Datamaterialet i studien er en del av forskningsrådsprosjektet DigiHand (2018-2021), ledet av Høgskulen i Volda i samarbeid med Lesesenteret ved Universitetet i Stavanger (Gamlem et al., 2020).

\section{Utvalg}

65 barneskoler i Norge ønsket å delta i studien, og 33 skoler ble selektert basert på seleksjonskriterier: (1) Flere enn 10 elever i hvert klasserom. (2) Bruk av nynorsk som hovedmål i klassen, for å sikre at testmålene blir like for alle, siden det er ulike nyanser i de to skriftspråkene i Norge, nynorsk og bokmål. (3) Skolene skal representere ett av tre vilkår, enten a) personlig nettbrett og utsatt håndskrift første året, b) personlig nettbrett og håndskriftsinstruksjon med blyant første året, eller c) håndskriftsinstruksjon første året (Gamlem et al., 2020). Det siste kriteriet er ment å kunne inngå som en del av et naturlig eksperiment for en oppfølgingsstudie, så man skal kunne sammenligne resultatene mellom de tre vilkårene og se på eventuelle forskjeller mellom dem.

Skoler som hadde flere paralleller i 1. klasse, ble informert om at bare én av klassene ville bli trukket ut til deltakelse. For å få et utvalg som speiler norske klasserom, er bare elever i den offentlige skolen inkludert i datainnsamlingen; privatskoler var altså ekskludert. Det eneste unntaket fra den offentlige skolen er elever som ikke er i stand til å delta i individuell kartlegging på grunn av alvorlige funksjonshemninger.

I studien ble totalt 606 elever invitert, basert på at det skulle velges én klasse fra hver av de 33 skolene. På grunn av elevenes unge alder måtte foreldre gi samtykke til deltakelse, og 96,5 prosent av dem samtykket til at barnet skulle delta 
$(n=585)$. Kartleggingen mangler fullstendige data fra åtte av elevene, og disse er derfor tatt ut av denne studien, slik at studiens utvalg er 577 elever. Elevenes gjennomsnittsalder ved begynnelsen av 1. klasse var 6,06 år, og kjønnsrepresentasjonen var $51 \%$ gutter. $12,1 \%$ av foreldrene meldte at elevene hadde et annet morsmål enn norsk.

\section{Prosedyrer og måleinstrumenter}

Kartlegging av elevene ble gjennomført individuelt ved skolestart, og da i løpet av de to første ukene i september. I kartleggingen ble det brukt et nettbrett (iPad) der forsker satt sammen med eleven individuelt og introduserte ulike oppgaver som kartla elevens lese- og skriveferdigheter. Alle elevene i studien fikk de samme oppgavene. For å styrke studiens reliabilitet ble det før innsamling av data gjennomført et sertifiseringskurs for de som skulle samle inn data fra elevene, der tekniske og etiske hensyn ble drøftet. I tillegg ble praktiske og etiske hensyn gjennomgått med utgangspunkt i barnas unge alder.

For å kartlegge elevenes lese- og skriveferdigheter ble det utviklet et måleinstrument gjennom en app (Gamlem et al., 2020) som består av følgende variabler: fremlydsanalyse, bokstavgjenkalling, vokabular, lesing av ord, fonologisk syntese, staving av ord og bokstavkunnskap. Disse målene er basert på studier som har vært utviklet, benyttet og validert av forskerteam fra tidligere forskningsrådsprosjekter som På Sporet og Two Teachers (Lundetræ et al., 2017; Solheim et al., 2017; Solheim et al., 2018).

Fremlydsanalyse er et av flere mål i studien som kartlegger om eleven kan lytte ut første lyden i et ord. Dette er et mål på hvor langt elevene er kommet i sin utvikling av fonologisk bevissthet og er en fonologisk segmenteringsoppgave. Eleven får se et bilde av et objekt på skjermen. Forskeren sier hva det er bilde av, og eleven skal lytte ut første lyd i ordet. Et eksempel på en oppgave er: «Dette er eit eple. Kva er den første lyden i eple?» Forskeren registrerer om svaret er rett eller feil ved å trykke på nettbrettet. Denne delprøven består av to øvingsoppgaver og 10 ordinære oppgaver. Delprøven blir avbrutt automatisk etter to påfølgende feil, for at elever skal slippe å måtte gjøre mange oppgaver på rad som de trolig ikke mestrer. Hvert element får 1 eller 0 poeng, og maksimal skår er 10. Dette målet er utviklet av Solheim et al. (2018).

Bokstavgjenkalling kartlegger elevenes grafem til fonem-kunnskap eller evne til å koble bokstav og tilhørende lyd. Eleven ser små bokstaver på nettbrettet og blir bedt om å uttale lyden til bokstaven på skjermen. Bokstavene som barnet får se er: s, i, l, o, r, e, m, a, n, u, å, f, ø, b, v, t, g, j, y, h, k, d, p, æ. Testen har utelatt bokstavene c, q, w, x og z siden de er lite brukt i det norske alfabetet. Skårverdier går fra 0 til 24. Målet for bokstavgjenkalling er utviklet av Solheim et al. (2018).

Vokabular kartlegger elevenes ordforråd, som måler barnets ekspressive breddevokabular. Eleven får se en tegning og skal si hva det er bilde av. Det er til sammen 20 tegninger. Eksempler på bildetegninger er: vulkan, tiger, trekkspill, timeglass, iglo og armbånd. Alle elevene skal gjennomføre alle de 20 oppgavene. 
Testleder registrerer om svaret er rett eller feil, og skårverdier er fra 0 til 20. Dette målet er utviklet av Størksen et al. (2013).

Lese ord del 1 inneholder oppgaver med ulik vanskelighetsgrad som måler elevenes evne til å lese og forstå ord. Denne delprøven kartlegger om eleven kan lese enkle ord. Eleven får se et ord på skjermen og skal prøve å lese hva som står. Eleven får totalt ti ord, og eksempler på ord er: is, sol, mus, kake og bamse. Delprøve 1 blir avbrutt etter to feil på rad, og scoringsverdier er fra 0 til 10. Dette målet er utviklet av Lundetræ et al. (2017) og Solheim et al. (2018).

Lese ord del 2 kartlegger elevens leseflyt ved hjelp av lesing av enkle ord, med skårverdier fra 0 til 104. De elevene som klarer å lese tre eller flere ord i Lese ord del 1, får et ark med 104 enkeltord som er satt opp i en liste vertikalt som de skal lese. Forsker registrerer hvor mange ord eleven kan lese på 45 sekund. Dette målet er utviklet av Seymore, Aro og Erskine i 2003 og er beskrevet i Solheim et al. (2018).

Fonologisk syntese kartlegger elevens ferdighet i å trekke sammen bokstavlyder. Det er viktig å bruke bokstavlyder og ikke bokstavnavn. Det er to øvingsoppgaver og åtte ordinære oppgaver der skårverdier var fra 0 til 8. Et eksempel på en oppgave er: Elevene blir bedt om å se på en bilderamme av bildene sol - bok - sel - ost. Så blir de bedt om å høre godt etter og så trykke på bildet som passer til s-o-l på nettbrettet. Oppgaven blir avbrutt etter to feil på rad. Dette målet er utviklet av Lundetræ et al. (2017) og Solheim et al. (2018).

Stave ord måler elevenes staveferdighet, og består av en øvingsoppgave og ti ordinære oppgaver (skår fra 0 til 10). Lærer leser først en setning fra nettbrettet og gjentar så ett av ordene i setningen og ber eleven skrive det ned med blyant på et utdelt papir. Eksempelvis: «Eg likar å le. Skriv le.» Delprøven blir avsluttet automatisk dersom eleven gjør to feil på rad, noe som forskeren vil markere uten at eleven ser det, siden skjermen på nettbrettet er skjult for eleven. Målet for å stave ord er utviklet av Solheim et al. (2018).

Bokstavkunnskap er et mål på elevens kunnskap om bokstavene i alfabetet, eller mer nøyaktig elevenes fonem til grafemkunnskap. Eleven får høre en bokstav og peker på bokstaven han/hun mener hører sammen med lyden. Det er store bokstaver som blir testet. Oppgaven skårer fra 0 til 24 og består av 24 av de 29 bokstavene i det norske alfabetet (unntatt c, q, w, x og z) i vilkårlig rekkefølge. Målet er utviklet av Solheim et al. (2018).

\section{Analyser}

I studien er målet for bokstavkunnskap brukt for å dele utvalget inn i to grupper, basert på skår (se neste avsnitt). Denne delingen med vekt på bokstavkunnskap er basert på forskning om at bokstavkunnskap fremstår som en særlig viktig faktor i begynneropplæringen, og er med på å styrke barns vokabular (f.eks. Hagtvet et al., 2011). Med utgangspunkt i hvor viktig bokstavkunnskap er for den første leseog skriveutviklingen, ble denne variabelen valgt ut som utgangspunkt for en analyse av elevene med lavest mestring på lese- og skriveferdigheter. 
For å analysere elevenes lese- og skriveferdigheter utførte vi en deskriptiv statistikk ved å se på middelverdiene til de kartlagte variablene for hele utvalget (577 elever). Analysen ble gjort i SPSS. Videre ble en inndeling for nærmere analyse av elever med lavest mestring gjort basert på variabelen bokstavkunnskap, hvor de ca. 20 prosent av elevene med lavest skår ble plassert i en egen gruppe som vi kalte gruppe $1(n=109)$. De resterende elevene ble kategorisert som gruppe $2(n=468)$.

\section{Resultat}

Analyser for deskriptiv statistikk er gjennomført på hele utvalget ( $\mathrm{n}$ =577), og for gruppe $1(n=109)$ og gruppe $2(n=468)$. Tabell 1 representerer hele utvalget og viser middelverdi med standardavvik og oppnådd minimum- og maksimumverdi for de 8 variablene i kartleggingen.

Tabell 1 viser at elevene i det totale utvalget jevnt over har god kunnskap om bokstavene, siden de i gjennomsnitt kan 17,47 bokstaver allerede etter 3 uker på skolen, men variasjonen er stor når det gjelder denne variabelen $(S D=5,89)$. I tillegg viser bokstavgjenkallingen at elevene i gjennomsnitt kan 10,31 bokstaver $(S D=6,78)$ etter 3 uker skolegang, men også her er spredningen svært stor i utvalget. Det er også interessant å se at vokabularet er relativt høyt i starten av første klasse i utvalget vårt, og av 20 ord klarte elevene i gjennomsnitt å gjengi 13,40 ord $(S D=3,85)$.

Tabell 1. Tabell over variablene i kartleggingen for hele utvalget $(n=577)$

\begin{tabular}{|l|c|c|c|c|}
\hline Variabel & Min & Max & \multicolumn{1}{c|}{ M } & SD \\
\hline Fremlydsanalyse (FA) & 0 & 10 & 5,79 & 3,70 \\
\hline Bokstavgjenkalling (BGK) & 0 & 24 & 10,31 & 6,78 \\
\hline Vokabular (VO) & 0 & 20 & 13,40 & 3,85 \\
\hline Lese ord, del 1 (LO1) & 0 & 10 & 3,21 & 3,41 \\
\hline Lese ord, del 2 (LO2) & 0 & 60 & 2,82 & 6,81 \\
\hline Fonologisk syntese (FS) & 0 & 8 & 3,53 & 2,58 \\
\hline Stave ord (SO) & 0 & 10 & 2,14 & 3,15 \\
\hline Bokstavkunnskap (BK) & 0 & 24 & 17,47 & 5,89 \\
\hline
\end{tabular}

Note. Min og Max betegner minste og største verdi oppnådd av elevene.

Tabell 2 viser resultatene av de ulike lesemålene som ble gjennomført for gruppe 1 og gruppe 2. For å undersøke forskjellene mellom gruppene, ble det gjort en 2 sample $t$-test, der Glass’ $\Delta$ ble benyttet, som er et mål på effektstørrelse på basis av grupper med ulik utvalgsstørrelse, og der standardavvikene er signifikant ulike mellom gruppene (Glass et al., 1981). Som en ser i tabell 2, er alle effektstørrelsene av Glass' $\Delta$ store, med unntak av vokabulartesten (VO), som er middels stor $(0,55)$ (Glass et al., 1981). 
Tabell 2. Resultat av lese- og skrivemål for gruppe 1 og 2 for hver variabel $i$ kartleggingen

\begin{tabular}{|c|c|c|c|c|c|c|c|c|c|c|c|c|}
\hline \multirow{2}{*}{$\begin{array}{l}\text { Vari- } \\
\text { abel }\end{array}$} & \multicolumn{5}{|c|}{ Gruppe $1(n=109)$} & \multicolumn{5}{|c|}{ Gruppe $2(n=468)$} & \multirow{2}{*}{$\frac{2 \text { sample } t \text {-test }}{t(576)^{\star *}}$} & \multirow{2}{*}{$\begin{array}{r}\text { Effect size } \\
\text { Glass's } \Delta\end{array}$} \\
\hline & Min & Max & $M$ & SD & \%* & Min & Max & $M$ & SD & $\%^{*}$ & & \\
\hline FA & 0 & 10 & 2,91 & 2,99 & 29,1 & 0 & 10 & 6,45 & 3,53 & 64,5 & $-10,74$ & 1,16 \\
\hline BGK & 0 & 22 & 4,35 & 4,38 & 18,1 & 0 & 24 & 11,68 & 6,46 & 48,7 & $-10,95$ & 1,67 \\
\hline VO & 0 & 19 & 11,42 & 4,38 & 57,1 & 0 & 20 & 13,85 & 3,57 & 69,3 & $-5,39$ & 0,55 \\
\hline L01 & 0 & 10 & 0,86 & 1,40 & 8,6 & 0 & 10 & 3,74 & 3,50 & 37,4 & $-8,43$ & 2,06 \\
\hline LO2 & 0 & 5 & 0,38 & 1,99 & 0,4 & 0 & 60 & 3,35 & 7,63 & 3,2 & $-7,38$ & 1,49 \\
\hline FS & 0 & 7 & 1,94 & 1,85 & 24,3 & 0 & 8 & 3,88 & 2,58 & 48,5 & $-9,08$ & 1,05 \\
\hline so & 0 & 6 & 0,29 & 0,98 & 2,9 & 0 & 10 & 2,55 & 3,32 & 25,5 & $-12,56$ & 2,31 \\
\hline$B K$ & 0 & 11 & 8,01 & 2,48 & 33,4 & 12 & 24 & 19,71 & 3,87 & 82,1 & $-39,34$ & 4,72 \\
\hline
\end{tabular}

Note. $\mathrm{FA}=$ Fremlydsanalyse, $\mathrm{BGK}=$ Bokstavgjenkalling, $\mathrm{VO}=$ Vokabular, $\mathrm{LO}=$ Lese ord del 1, LO2 = Lese ord del 2, FS = Fonologisk syntese, SO = Stave ord, BK (rad i kursiv) = Bokstavkunnskap (variabelen som er utgangspunkt for gruppeinndelingen).

* \% indikerer prosent riktige svar av maksimumskåren som er mulig å oppnå for hvert av målene.

** Alle $t$-test-resultatene har signifikansverdier $p<0,0001$.

Gjennom en deskriptiv analyse av lese- og skrivemål for gruppe 1 og gruppe 2 kommer det frem hva som er forskjeller mellom gruppene basert på middelverdier og prosent riktig (se tabell 2 og figur 1).

Figur 1. Resultat basert på prosent riktige skår for gruppe $1(\mathrm{n}=109)$ og gruppe $2(\mathrm{n}=468)$

\section{Prosent riktige skår}

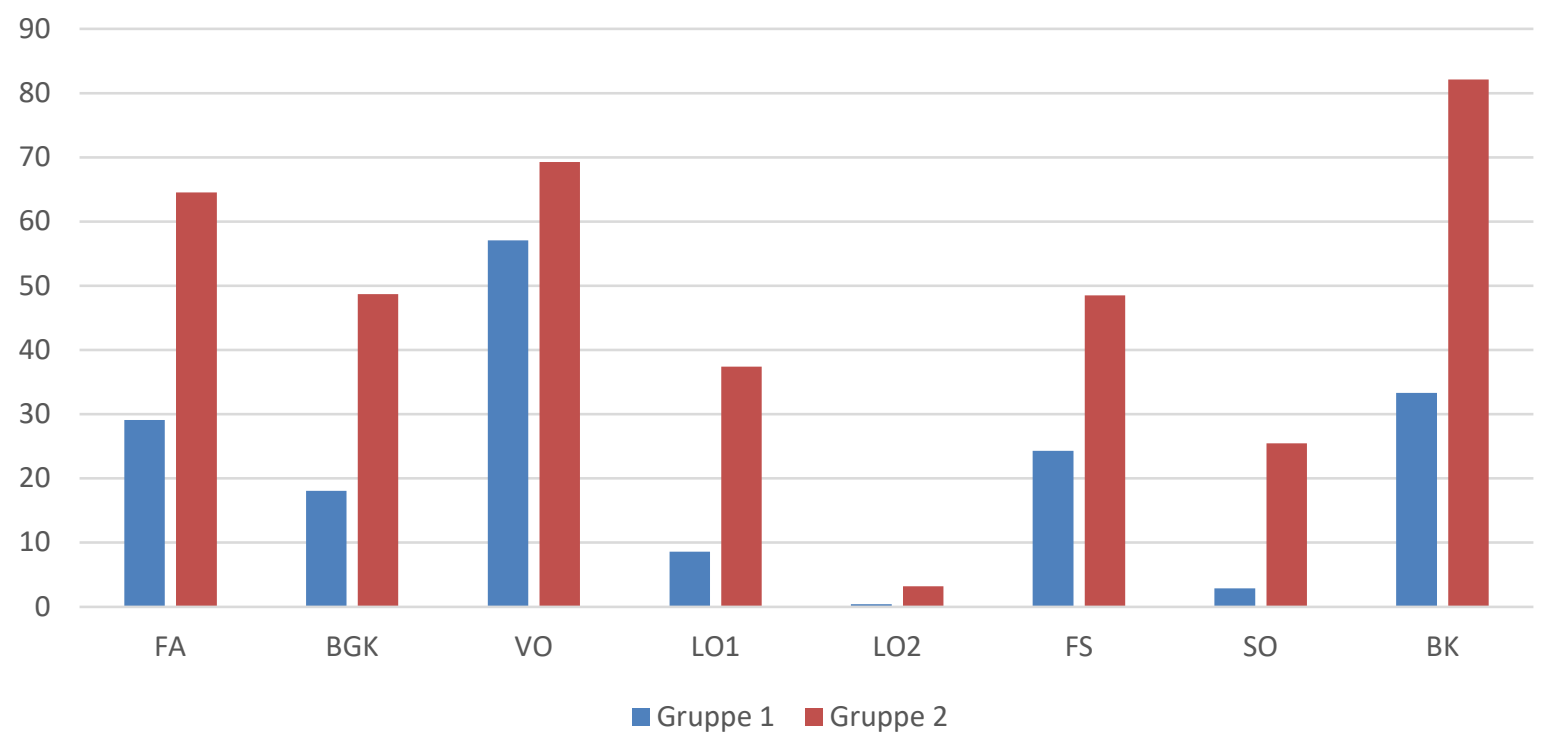

Note. FA = Fremlydsanalyse, $\mathrm{BGK}=$ Bokstavgjenkalling, $\mathrm{VO}=$ Vokabular, $\mathrm{LO} 1=$ Lese ord del 1, LO2 $=$ Lese ord del 2, FS = Fonologisk syntese, $\mathrm{SO}=$ Stave ord, $\mathrm{BK}=$ Bokstavkunnskap.

Som vist i figur 1 og tabell 2 var det størst forskjell i middelverdi mellom de to gruppene på variablene fremlydsanalyse og bokstavgjenkalling. Siden skår på bokstavkunnskap er seleksjonsgrunnlaget for analysen, blir forskjellen mellom gruppene på denne variabelen ikke kommentert her.

Når det gjelder variabelen fremlydsanalyse, det vil si om eleven kan lytte ut første lyden i et ord, viser analysen at det er tydelige forskjeller mellom gruppene. Mens gruppe 2 har en middelverdi på 6,45 $(S D=3,53)$ på fremlydsanalyse, hadde 
gruppe 1 en middelverdi på 2,91 $(S D=2,99)$. En $t$-test viste at forskjellen mellom gruppene var stor: $t(576)=-10,74$, Glass’ $\Delta=1,16$.

Resultatene på variabelen bokstavgjenkalling, som måler elevenes forståelse av en bokstav, viste at gruppe 2 har en middelverdi på 11,68 bokstaver ( $S D=$ $6,46)$, mens gruppe 1 hadde en middelverdi på 4,35 bokstaver $(S D=4,38)$. Resultatet av analysen viser at det også her var stor forskjell mellom de to gruppene: $t(576)=-10,95$, Glass’ $\Delta=1,67$.

På vokabulartesten var det også noe forskjell mellom gruppene. Elevene i gruppe 2 hadde en middelverdi på 13,85 ord $(S D=3,57)$ og elevene i gruppe 1 hadde en middelverdi på 11,42 ord $(S D=4,38)$, og forskjellen var middels stor: $t(576)=-5,39$, Glass' $\Delta=0,55$. Resultatet viser at totalt sett hadde elevene lært mange ulike ord i starten av første klasse, men at det likevel er forskjell mellom de to gruppene på denne variabelen.

Ved lesing av ord viste analysen også forskjeller mellom de to gruppene. Gruppe 2 leste i gjennomsnitt 3,74 ord $(S D=3,50)$, mens gruppe 1 i gjennomsnitt leste 0,86 ord $(S D=1,40)$. Forskjellen mellom de to gruppene var også her stor: $t(576)=-8,43$, Glass' $\Delta=2,06$.

Det var også stor forskjell mellom gruppene når det gjaldt lesing av en lengre rekke med ord. Elevene i gruppe 2 leste i gjennomsnitt 3,35 ord $(S D=7,63)$, mens elevene i gruppe 1 i gjennomsnitt leste 0,38 ord $(S D=1,99), t(576)=-7,38$, Glass' $\Delta=1,49$. Resultatene viser at de færreste elevene i gruppe 1 maktet å lese et helt ord på delprøve 2, mens det var noen få elever i gruppe 2 som leste hele 60 ord på 45 sekunder.

Videre var det stor forskjell mellom gruppene når det gjaldt fonologisk syntese, det vil si hvor mange bokstavlyder elevene klarte å trekke sammen. Gruppe 1 trakk i gjennomsnitt sammen 1,94 bokstaver $(S D=1,85)$, mens gruppe 2 i gjennomsnitt trakk sammen 3,88 bokstaver $(S D=2,58)$. En $t$-test viste at forskjellen mellom gruppene var stor: $t(576)=-9,08$, Glass’ $\Delta=1,05$.

Når det gjaldt skrivemålet for staving av ord, var det få i gruppe 1 som mestret å stave et helt ord $(M=0,29, S D=0,98)$, mens middelverdien i gruppe 2 var 2,55 ord $(S D=3,32)$. $t$-testen viste at det var stor forskjell mellom gruppe 1 og gruppe 2 også her: $t(576)=-12,56$, Glass' $\Delta=2,31$. Det var altså relativt lav skår på staving av ord, men også her var forskjellen mellom de to gruppene tydelig.

På målet for bokstavkunnskap var det som ventet stor forskjell mellom gruppene, men siden forskjeller i denne variabelen også var utgangspunktet for oppdelingen av de to gruppene i analysen, har det ingen hensikt å fremheve denne i analysen, og den er derfor markert med kursiv i tabell 2. 


\section{Drøfting}

\section{Store forskjeller mellom elever}

Målet med denne studien er å studere hva som kjennetegner lese- og skriveferdighetene til elever ved skolestart på 1. trinn, med en vektlegging av elever som strever med bokstavkunnskap. Utvalget som er hentet fra 33 klasser i Norge, kan si noe om hva som kjennetegner lese- og skriveferdighetene til disse elevene. Hovedfunnene fra studien indikerer at det er store forskjeller mellom gruppe 1 (de ca. 20 \% av elevene med lavest skår på variabelen bokstavkunnskap) og gruppe 2 (resten av elevgruppen), særlig på målene fremlydsanalyse og bokstavgjenkalling. Resultatene viser at det også er store forskjeller mellom de to gruppene når det gjelder alle de øvrige målene. Ettersom flere av målene innebærer elementer av fonologisk bevissthet på ulike måter, kan de store forskjellene mellom gruppene også forklares ettersom de alle er basert på forskjeller i bokstavkunnskap.

Resultatene på målene for lesing av ord 1 og lesing av ord 2 indikerer en gulveffekt, da svært få elever i gruppe 1 presterer på disse målene. Dette kan indikere at disse testene kan være noe uegnet $\mathrm{i}$ begynnelsen av 1 . trinn, fordi elevene bare hadde noen få riktige svar på disse variablene.

\section{Fremlydsanalyse og bokstavgjenkalling}

Elever som har lav mestring i bokstavkunnskap når de begynner på skolen, ser også ut til å ha lavere skår enn sine medelever på målene fremlydsanalyse og bokstavgjenkalling. Disse variablene er de som gir størst forskjell mellom gruppe 1 og gruppe 2 i studien. Cain (2010) understreker betydningen av fonologisk analyse og det å kunne lytte ut lyder for å kunne lese ord. Videre hevder Cain (2010) at fonologisk omkoding er en ferdighet som bidrar til elevenes leseforståelse, og i tillegg spiller inn på barns evne til å gjenkjenne, bearbeide og gjenkalle språkets fonologiske struktur, som danner et svært viktig grunnlag for et barns lese- og skriveutvikling (Cain, 2010; Gough \& Tunmer, 1986; Hoover \& Gough, 1990).

Analysene viser altså at det kan være en særlig utfordring som kommer til syne ved målene fonologisk analyse og bokstavgjenkalling, siden forskjellene er så store mellom gruppene her. Disse ferdighetene spiller også inn på lesing av ord, som er i nærheten av null $(0,95)$ og derfor får en gulveffekt for gruppe 1. For elevene i gruppe 2 er flere bokstaver allerede kjent, og det kan derfor være enklere for disse elevene med en rask progresjon i bokstavinnlæringen, enn for elevene med lavest mestring (gruppe 1). Elevene i gruppe 2 kjenner ved oppstart i 1. klasse i gjennomsnitt igjen 11,68 bokstaver, mens elevene i gruppe 1 i gjennomutsnitt kjenner igjen 4,35 bokstaver. Dette resultatet kan sees i lys av Sigmundsson et al. (2017) som fant at barn i gjennomsnitt kunne kjenne igjen færre enn halvparten av både store og små bokstaver i det norske alfabetet ved skolestart. Man ser at forskjellene i bokstavgjenkalling er store blant elevene i vår studie. McTigue et al. (2020) finner at de fleste elevene kan kjenne igjen store bokstaver, noe som 
ikke helt samsvarer med vår studie. Imidlertid finner McTigue et al. (2020) at det er stor variasjon i elevene sine ferdigheter når det gjelder bokstavgjenkalling, noe som samsvarer med vår studie. Med mulighet til å øve på alle bokstavene over en lengre periode, også gjennom lesing og skriving, kan lærerne vite om elevene strever med å lære bokstavene på et tidlig tidspunkt.

Ved fonologisk syntese, eller evnen til å kunne trekke bokstavlyder sammen til ord, er det i vår studie en stor forskjell mellom gruppe 1 og 2 (se tabell 2). Resultatene viser at fonologisk analyse er en kritisk variabel når det gjelder gruppen med lavest mestring (gruppe 1), og noe som skiller dem fra de andre elevene på 1. trinn. Samtidig viser lave ferdigheter i fonologisk syntese og analyse å kunne være en risikofaktor for å utvikle dysleksi hos barn (Snowling et al., 2019).

Studien viser også at det store forskjeller mellom gruppe 1 og 2 i fremlydsanalyse, noe som er knyttet til avkodingsaspektet ved lesing og evnen til å skille ut bokstavlyder fra ord. Det er ingen forutsetning at elevene skal ha lært bokstaver når de begynner på skolen, men vi ser av våre resultater at elevene kommer til skolen med svært ulike forutsetninger. Mer systematisk arbeid med bokstaver ved skolestart kan være gunstig, og det samme gjelder arbeid med å lytte ut lyder med hensyn til fonologisk syntese.

\section{Vokabularets betydning}

Når det gjelder resultat av vokabularet til elevene i vår studie, er dette rimelig høyt for alle elevene vi testet. I skolen er det viktig at barna har et vokabular, eller ordforråd, og kan kommunisere godt, men det er et spørsmål hvor sentralt det er i lese- og skriveopplæringen. Resultat fra denne studien viser at gruppe 1 har en relativt høy mestring og følger kurven til de andre elevene (gruppe 2). Dette er noe uventet i forhold til tidligere studier som fremhever at ordforrådet hos elever med lav mestring kan være dårlig (Catts et al., 2002; McArthur et al., 2000; Walgermo, 2018). En forklaring på dette kan være at vokabulartesten vi brukte er for snever og har et begrenset antall items. Med en større og mer utviklet vokabulartest kan en trolig ha fått et annet resultat, noe som kan ha hatt en innvirkning på resultatet.

Samtidig vet vi at når elever begynner på skolen, har de et utvidet vokabular og mestrer de fleste syntaktiske mønstre (Lyster, 2009). Det styrker også forskningen til Biemiller (2005) som hevder at barn forstår flere ord, uttrykk og setningsstrukturer enn det de selv bruker, og vil etter hvert også ta denne kunnskapen i bruk i sin egen tale. Biemiller (2005) finner store forskjeller i barns vokabular ved skolestart. Dette kan ha ulike årsaker, men studier viser at i barnehager i Norge er det mye språkstimulering og vektlegging av ordforråd, mens det er mindre vektlegging av bokstaver og bokstavgjenkalling (f.eks. Håberg \& Gamlem, 2018). Håberg og Gamlem (2018) finner at femårsklubben i barnehagen i Norge gjerne består av fargelegging, bruk av begreper, og samtale om gjenstander. Barnehagen (barn 0-6 år) har ikke noe klart mandat med hensyn til 
å drive forberedelse til lese- og skriveopplæring, men det er mulig at arbeid med ord og begreper i barnehagen gjør at elevenes vokabular jevnt over er relativt stort.

\section{Andre variabler}

Når det gjelder målet Lese ord del 1, presterer gruppe 1 lavt (se tabell 2), men det er ikke så store forskjeller mellom gruppe 1 og gruppe 2 på denne variabelen, som det er på variablene fremlydsanalyse og bokstavgjenkalling. Her er det i stor grad så enkelt som at enten kan eleven lese, eller så kan eleven det ikke. Det var få elever i gruppe 1 som klarte å vise mestring på målet Lese ord 2, og totalt sett var det bare noen få av elevene i gruppe 2 som kunne lese ord ved oppstart i 1 . klasse. Det gjør måling av den variabelen dårlig egnet til å dra konklusjoner utenom den selvfølgelige, at elever i gruppe 1 gjør det svakt. Dette samsvarer også med studien til McTigue et al. (2020) som fant at svært få førsteklasseelever var lesere ved skolestart, og at det var stor variasjon i elevene sine ferdigheter. Samtidig styrker våre analyser inntrykket av at få elever klarer å lese ord når de begynner på skolen, og at spredningen i ordlesing er svært stor ved skolestart.

\section{Oppsummering, implikasjoner og videre forskning}

Den store forskjellen blant elevene på bokstavgjenkalling og fremlydsanalyse er hovedfunnet i undersøkelsen. Resultat i studien fremhever viktigheten av arbeid med bokstaver, fonologisk bevissthet og tilpasset opplæring tidlig i skrive- og leseopplæringen. For å få mer kunnskaper om elevers lese- og skriveferdigheter og utfordringer i begynneropplæringen, er det behov for studier som ser på sammenhenger mellom ulike mål for disse ferdighetene og andre karakteristika som for eksempel elevenes kjønn, alder og flerspråklighet. Det trengs også mer forskning på hvordan faktorer rundt elevenes hjemme- og skolemiljø spiller inn på elevenes lese- og skriveferdigheter i første klasse. Studier som ser på hvordan elever med lav mestring i bokstavkunnskap videreutvikler lese- og skriveferdigheter over tid, vil også kunne gi et grunnlag til å forstå elevers utfordringer i begynneropplæringen.

Resultatene fra studien fremhever behovet for tilrettelegging av den første lese- og skriveopplæringen, og påpeker behovet for tilpasset opplæring som gir alle elever en mulighet for læring og utvikling, spesielt når det gjelder bokstavprogresjon, og kan hindre at forskjellene øker med årene (Stanovich, 1986). Vi vil argumentere for at det er viktig at lærerne er oppmerksomme på den store spredningen i mestringsnivået på ulike mål for lese- og skriveopplæringen ved skolestart. Det er i dag en diskusjon om behovet for kartlegging allerede i barnehagene, men også en diskusjon om dette skal innføres (Klem \& Hagtvet, 2018). Når det gjelder kartlegging, blir det viktig å velge egnede undersøkelsesformer som gir mening for så unge elever, for å forhindre at man får usikre, eller manglende resultater. Samtidig ser man at tidlig kartlegging av elevenes lese- og 
skriveferdigheter kan gi mulighet for å avdekke, belyse og gripe fatt i utfordringer i elevenes opplæring, og slik legge til rette undervisningen for å støtte deres leseog skriveopplæring.

\section{Takk}

Artikkelen er basert på data fra FINNUT-prosjektet DigiHand (2018-2021) som er finansiert gjennom Norges Forskningsråd (NFR), prosjektnummer 273422. En stor takk til alle DigiHand-medlemmene som har samlet inn data, og en særlig takk til Per Henning Uppstad, Bente Rigmor Walgermo og Irene Bele for nyttige innspill på tidligere utkast av artikkelen.

\section{Om forfatterne}

Wenke Mork Rogne er førsteamanuensis i norsk i lærerutdanningen på Høgskulen i Volda. Forskningsfeltet er multippel tekstforståelse, tidlig literacy, skriveutvikling og digitale verktøy, læringsprosesser og vurdering.

Institusjonstilknytning: Institutt for språk og litteratur, Høgskulen i Volda, Postboks 500, 6101 Volda, Norge.

E-post: wenke.mork.rogne@hivolda.no

Siv Måseidvåg Gamlem er professor i pedagogikk i lærerutdanningen på Høgskulen i Volda. Hun forsker på læringsprosesser, vurdering, selvregulert læring, feedback og dialogisk undervisning.

Institusjonstilknytning: Institutt for pedagogikk, Høgskulen i Volda, Postboks 500, 6101 Volda, Norge.

E-post: sivmg@hivolda.no

Randi Lyngbø Ottesen er høgskolelektor i pedagogikk i lærerutdanningen på Høgskulen i Volda. Hun har en master i spesialpedagogikk og forsker på barns lese- og skriveutvikling.

Institusjonstilknytning: Institutt for pedagogikk, Høgskulen i Volda, Postboks 500, 6101 Volda, Norge.

E-post: randi.lyngbo.ottesen@hivolda.no 


\section{Referanser}

Alexander, A. W., Andersen, H. G., Heilman, P. C., Voeller, K. K. S. \& Torgesen, J. K. (1991). Phonological awareness training and remediation of analytic decoding deficits in a group of severe dyslexics. Annals of Dyslexia, 41, 193-206. https://doi.org/10.1007/BF02648086

Biemiller, A. (2005). Size and Sequence in Vocabulary Development: Implications for Choosing Words for Primary Grade Vocabulary Instruction. I E. H. Hiebert \& M. L. Kamil (red.), Teaching and learning vocabulary: Bringing research to practice (s. 223242). Lawrence Erlbaum Associates Publishers.

Cain, K. (2010). Reading development and difficulties. UK: BPS Blackwell Publishing.

Catts, H. W., Fey, M. E., Tomblin, J. B. \& Zhang, X. (2002). A longitudinal investigation of reading outcomes in children with language impairments. Journal of Speech, Language and Hearing Research, 45(6), 1142-1157. https://doi.org/10.1044/10924388(2002/093)

Chard, D. J. \& Kameenui, E. J. (2000). Struggling First-Grade Readers: The Frequency and Progress of Their Reading. Journal of Special Education, 34 (1), 28-38. https://doi.org/10.1177\%2F002246690003400103

Chen, R. S. \& Vellutino, F. R. (1997). Prediction of Reading Ability: A Cross-Validation Study of the Simple View of Reading. Journal of Literacy Research, 29(1), 1-24. https://doi.org/10.1080/10862969709547947

Gamlem, S. M., Rogne, W. M., Rønneberg, V. \& Uppstad, P. H. (2020). Study protocol: DigiHand - the emergence of handwriting skills in digital classrooms. Nordic Journal of Literacy Research, 6(2), 25-41. http://dx.doi.org/10.23865/njlr.v6.2115

Georgiou, G. K., Das, J. P. \& Hayward, D. (2009). Revisiting the "Simple View of Reading” in a Group of Children with Poor Reading Comprehension. Journal of Learning Disabilities, 42(1), 76-84. https://doi.org/10.1177/0022219408326210

Glass, G. V., McGaw, B. \& Smith, M. L. (1981). Meta-Analysis in Social Research. Beverly Hills: Sage Publishers.

Gough, P. B. \& Tunmer, W. E. (1986). Decoding, reading, and reading disability. Remedial and Special Education, 7(1), 6-10. https://doi.org/10.1177\%2F074193258600700104

Hagtvet, B. E., Lyster, S.-A. H., Melby-Lervåg, M., Næss, K.-A., Hjetland, H. N., Engevik, L. I., Hølland, S., Karlsen, J., Klem, M. \& Kruse, J. (2011). Ordforråd i førskolealder og senere leseferdigheter - En metaanalytisk tilnærming. Spesialpedagogikk, 1, 34-49. https://utdanningsforskning.no/artikler/2011/ordforrad-i-forskolealder-og-senereleseferdigheter--en-metaanalytisk-tilnarming/

Hoover, W. A. \& Gough, P. B. (1990). The simple view of reading. Reading and Writing, 2, 127-160. https://doi.org/10.1007/BF00401799

Hulme, C., Nash, H. M., Gooch, D., Lervåg, A. \& Snowling, M. J. (2015). The foundations of literacy development in children at familial risk of dyslexia. Psychological Science, 26(12), 1877-1886. https://doi.org/10.1177/0956797615603702

Hulme, C. \& Snowling, M. J. (2009). Developmental disorders of language learning and cognition. Chichester: Wiley-Blackwell.

Håberg, L. I. A. \& Gamlem, S. M. (2018). Tilbakemelding for læring på femårsklubb i barnehagen. FoU i praksis, (1), 7-26.

Klem, M. \& Hagtvet, B. E. (2018). Tidlig språkkartlegging, til barnets beste? Norsk Tidsskrift for Logopedi, 4, 12-24. http://urn.nb.no/URN:NBN:no-74650 
Lonigan, C. J., Burgess, S. R. \& Anthony, J. L. (2000). Development of emergent literacy and early reading skills in preschool children: Evidence from a latent-variable longitudinal study. Developmental psychology, 36(5), 596-613. https://doi.apa.org/doi/10.1037/00121649.36.5.596

Lundetræ, K., Solheim, O. J., Schwippert, K. \& Uppstad, P .H. (2017). Protocol: ‘On Track’, a group-randomized controlled trial of an early reading intervention. International Journal of Educational Research, 86, 87-95. https://doi.org/10.1016/j.ijer.2017.08.011

Lyster, S. A. H. (2009). Ordforråd og leseutvikling. I J. Frost (red.), Språk og leseveiledning i teori og praksis (s. 231-251). Oslo: Cappelen Damm.

McArthur, G. M., Hogben, J. H., Edwards, V. T., Heath, S. M. \& Mengler, E. D. (2000). On the "specifics" of specific reading disability and specific language impairment. Journal of Child Psychology and Psychiatry and Allied Diciplines, 41(7), 869-874. https://pubmed.ncbi.nlm.nih.gov/11079429/

McTigue, E. M., Schwippert, K., Uppstad, P. H., Lundetræ, K. \& Solheim, O. J. (2020). Gender differences in early literacy: Boys' response to formal instruction. Journal of Educational Psychology, advance online publication. https://doi.org/10.1037/edu0000626

Nation, K. (2019). Children's reading difficulties, language, and reflections on the simple view of reading. Australian Journal of Learning Difficulties, 24(1), 47-73. https://doi.org/10.1080/19404158.2019.1609272

Ouellette, G. P. (2006). What's meaning got to do with it: The role of vocabulary in word reading and reading comprehension. Journal of Educational Psychology, 98(3), 554-566. https://doi.org/10.1037/0022-0663.98.3.554

Shaywitz, S. E., Fletcher, J. M., Holahan, J. M., Shneider, A. E., Marchione, K. E., Stuebing, K. K., Francis, D. J., Pugh, K. R. \& Shaywitz, B. A. (1999). Persistence of dyslexia: The Connecticut longitudinal study at adolescence. Pediatrics, 104(6), 1351-1359. https://pediatrics.aappublications.org/content/104/6/1351

Sigmundsson, H., Eriksen, A. D., Ofteland, G. S. \& Haga, M. (2017). Letter-Sound Knowledge: Exploring Gender Differences in Children When They Start School Regarding Knowledge of Large Letters, Small Letters, Sound Large Letters, and Sound Small Letters. Frontiers in psychology, 8, 1-6. https://doi.org/10.3389/fpsyg.2017.01539

Snowling, M. J. \& Melby-Lervåg, M. (2016). Oral language deficits in familial dyslexia: A meta-analysis and review. Psychological Bulletin, 142(5), 498-545. http://dx.doi.org/10.1037/bul0000037

Snowling, M. J., Nash, H. M., Gooch, D. C., Hayiou-Thomas, M. E. \& Hulme, C. (2019). Developmental Outcomes for Children at High Risk of Dyslexia and Children with Developmental Language Disorder. Child Development, 90(5) 548-564. https://doi.org/10.1111/cdev.13216

Solheim, O. J., Frijters, J. C., Lundetræ, K. \& Uppstad, P. H. (2018). Effectiveness of an early reading intervention in a semi-transparent orthography. A group randomized controlled trial. Learning and instruction, 58, 65-79. https://doi.org/10.1016/j.learninstruc.2018.05.004

Solheim, O. J., Rege, M. \& McTigue, E. (2017). Study protocol: “Two Teachers”: A randomized controlled trial investigating individual and complementary effects of teacher-student ratio in literacy instruction and professional development for teachers. International Journal of Educational Research, 86, 122-130. https://doi.org/10.1016/j.ijer.2017.09.002

Spear-Swerling, L. \& Sternberg, R. J. (1994). The Road not taken: An integrative theoretical model of reading disability. Journal of learning disabilities, 27(2), 91-103. https://psycnet.apa.org/doi/10.1177/002221949402700204 
Stanovich, K. E. (1986). Matthew Effects in Reading: Some Consequences of Individual Differences in the Acquisition of Literacy. Reading Research Quarterly, 21(4), 360-407. https://www.psychologytoday.com/files/u81/Stanovich_1986_.pdf

Størksen, I., Ellingsen, I. T., Tvedt, M. S. \& Idsøe, E. M. (2013). Norsk vokabulartest (NVT) for barn i overgangen mellom barnehage og skole: Psykometrisk vurdering av en nettbasert test. Spesialpedagogikks Forskningsdel, 4(13), 40-54.

Torgesen, J. K. (1991). Learning disabilities: Historical and conceptual issues. I B. Y. L. Wong (red.), Learning about learning disabilities (s. 3-37). New York: Academic Press.

UDI R (2020). Utdanningsspeilet 2020. Oslo: Utdanningsdirektoratet. https://www.udir.no/tall-og-forskning/finn-forskning/tema/utdanningsspeilet-2020/

Walgermo, B. R. (2018). Motivation for Reading within the First Year of Formal Reading Instruction. Doktoravhandling, Universitetet i Stavanger. http://hdl.handle.net/11250/2581009

Walgermo, B. R., Frijters, J. C. \& Solheim, O. J. (2018). Literacy interest and reader selfconcept when formal reading instruction begins. Early Childhood Research Quarterly, 44, 90-100. https://doi.org/10.1016/j.ecresq.2018.03.002 